\title{
Mineral trioxide aggregate as an apical plug in infected immature teeth: a case series
}

\section{Agregado trióxido mineral como material de selamento apical em dentes com rizogênese incompleta: uma série de casos}

\section{Abstract}

Purpose: The purpose of this article is to present three clinical cases of infected immature teeth that were treated by using mineral trioxide aggregate (MTA) as an apical plug.

Cases Description: All cases underwent premature interruption of root development as consequence of pulp necrosis. Root canals were instrumented by using chlorhexidine gel $2 \%$ $(\mathrm{CHX})$ as auxiliary chemical substance. A paste of calcium hydroxide and $\mathrm{CHX}$ was kept for one-week as intracanal dressing. In a second appointment, the apical portion of the canals $(3-4 \mathrm{~mm})$ was filled with MTA. The remaining portions of the root canals were then obturated by the thermomechanical technique by utilizing gutta-percha condensers and a zinc oxide and eugenol-based root canal sealer. Follow-up periods at both 6 months and 1 year showed radiographic favorable response and absence of symptoms.

Conclusion: MTA seems to be nowadays, an interesting option of treatment for cases of immature teeth with the advantage of shorter treatment approaches.

Key words: Apexification; Endodontics; pulp necrosis; root canal filling

\section{Resumo}

Objetivo: $O$ objetivo desse artigo é descrever três casos clínicos de dentes com rizogênese incompleta e necrose pulpar tratados com agregado trióxido mineral (MTA) para obtenção de barreira de selamento apical.

Descrição dos casos: Todos os casos relatados apresentaram interrupção da formação radicular como consequência da necrose pulpar. Os canais foram instrumentados utilizando gel de clorexidina a $2 \%$ como substância química auxiliar e medicados com pasta de hidróxido de cálcio e clorexidina, a qual foi mantida nos canais por uma semana. Em uma segunda consulta, a porção apical dos canais foi selada com barreira apical de MTA, com espessura de aproximadamente 3-4 $\mathrm{mm}$. As demais porções dos canais foram obturadas com técnica de plastificação termomecânica da guta-percha, utilizando cimento à base de óxido de zinco e eugenol. Controle pós-operatório de 6 meses e 1 ano mostraram resposta radiográfica satisfatória e ausência de sintomas.

Conclusão: Atualmente, MTA apresenta-se como uma opção interessante para casos de rizogênese incompleta e necrose pulpar, apresentando como vantagem o menor tempo de tratamento requerido.

Palavras-chave: Apexificação; Endodontia; necrose da polpa dentária; obturação do canal radicular

\author{
Matheus Albino Souza a \\ João Vicente Barbizam b \\ Doglas Cecchin b \\ Roberta Kochenborger Scarparo ${ }^{a}$
}

- School of Dentistry, Pontifícia Universidade Católica do Rio Grande do Sul, Porto Alegre, RS, Brazil

b School of Dentistry, Universidade de Passo Fundo, Passo Fundo, RS, Brazil

\section{Correspondence:}

Roberta Kochenborger Scarparo

Av. Ipiranga, 6681 - Prédio 6

Porto Alegre, RS - Brasil

90619-900

E-mail:robks@terra.com.br

Received: April 12,2011

Accepted: July 20, 2011

Conflict of Interest Statement: The authors state that there are no financial and personal conflicts of interest that could have inappropriately influenced their work.

Copyright: (C) 2011 Souza et al.; licensee EDIPUCRS This is an Open Access article distributed under the terms of the Creative Commons AttributionNoncommercial-No Derivative Works 3.0 Unported License. 


\section{Introduction}

One of the most significant technical difficulties of endodontic treatment in infected immature teeth is to obtain a proper sealing of the root canal system. The absence of a natural constriction at the apical portion reduces the control to maintain the filling material confined into the root canals (1).

On this regard, calcium hydroxide $\left(\mathrm{CaOH}_{2}\right)$ has historically been used to establish apical closure by inducing apexification. This technique, first introduced by Kaiser and later spread by Frank (1), allows hard tissue deposition at the end of the root. It restricts bacterial infection and establishes a suitable environment for periapical repair (2). Although calcium hydroxide apexification has a success rates in the mid-90\% range (3), important disadvantages have also been associated with its utilization. The need of multiple appointments, the long period of time for treatment completion, susceptibility to fracture (4) and coronal microleakage during treatment (5) are some of the disadvantages which could be mentioned. Also, the formed barrier, although apparently calcified, is in fact porous and sometimes contains small amounts of soft tissue (6).

Recently, mineral trioxide aggregate (MTA) was proposed as a potential material for apical sealing of infected immature teeth. It prevents the extrusion of filling material and also decreases the apical leakage. MTA is composed of fine hydrophilic particles that set in the presence of moisture (7). As a material for perforation repair, MTA offers many favorable properties, including good sealing ability (8), biocompatibility $(7,9)$, radiopacity, and moisture resistance (7). It is also capable of inducing the deposition of mineralized tissue, stimulating the regeneration of the dentin and providing satisfactory antibacterial activity (7).

Considering those properties, the use of MTA barriers for sealing the apical portion of immature teeth has been proposed, and has shown excellent results (2). The following reports demonstrate the treatment and favorable response of three cases of infected teeth which presented wide apexes sealed using MTA as apical plug.

\section{Cases description}

\section{Case 1}

A 16-year-old male, presenting good general health, was referred for endodontic treatment due to a dental trauma suffered in the left maxillary central incisor 4 years before. Clinical examination did not reveal crown fracture, coronary darkening or abnormal mobility. However, the tooth was unresponsive to cold test. Radiographic examination (Fig. 1A) revealed an immature tooth 9 with wide canal, open apex and extensive radiolucent lesion around the apex.

After anesthesia and rubber dam placement, endodontic access was performed following conventional guidelines. Pulp canal chamber was then irrigated using chlorhexidine gel 2\% (CHX) (Lenzafarm, Belo Horizonte, Brazil) in order to remove and neutralize necrotic tissues. The working length was determined, and root canal was prepared using \# 2, 3 and 4 Gates-Glidden burs (Dentsply Maillefer, Ballaigues,Switzerland) in the coronal and middle thirds. The apical third was enlarged up to a K-file \# 55, followed by the step-back technique using larger K-type hand files (Dentsply Maillefer, Ballaigues,Switzerland). 2\% chlorhexidine and saline solution were alternated during the whole instrumentation process. Final rinse with 17\% EDTA (Biodinâmica, Ibiporã, Paraná, Brazil) was also performed in order to remove the smear layer. Then, the canal was dried with absorbent paper points and a paste of $\mathrm{Ca}(\mathrm{OH})_{2}$ (Biodinâmica, Ibiporã, Paraná, Brazil) mixed with $\mathrm{CHX}$ $2 \%$ was placed into the root canal with the aid of a spiral Lentulo (Dentsply Maillefer, Ballaigues,Switzerland) using a low-speed hand-piece. Intracanal medication was kept for one week.

At the second appointment, root canal dressing was removed by repeated irrigation with saline solution and the root canal was dried with absorbent paper points (Dentsply, Petrópoilis-RJ, Brazil). MTA (Angelus, Londrina-PR, Brazil) was prepared according to the manufacturer's instructions and placed in the apical portion of root canal (3-4 mm) using the MTA carrier (1.6 mm, Dovgan Tip, USA), creating an apical barrier. After MTA placement, the mixture was adjusted on the walls of the canal using Shilder's plugger to the size of the canal. Periapical radiograph was taken to confirm the correct position and size of the MTA plug. Remaining root canal space was filled with CHX 2\% (Lenzafarm, Belo Horizonte-MG, Brazil) and a cotton pellet was placed into the pulp chamber below a provisory restoration with glass-ionomer cements (DFL, Rio de Janeiro-RJ, Brazil). After a week, the canal was irrigated with saline (Biodinâmica, Ibiporã, Paraná, Brazil) and dried with absorbent paper points. The set of the apical plug of MTA was gently tested. Remaining root canal space was obturated by the thermomechanical technique using gutta-percha condensers (Dentsply-Maillefer, Ballaigues, Switzerland), with a zinc oxide and eugenol-based sealer (EndoFill-Dentsply, Petrópolis-RJ, Brazil). Finally, the tooth was restored with composite resin (Z100 3M ESPE, Irvine, USA).

At both 6 months and one year follow-up, patient was clinically asymptomatic. Radiographs showed that the lesion had significantly decreased in size after 6 months (Fig. 1B). Complete radiographic healing was detected after 1 year (Fig. 1C). 


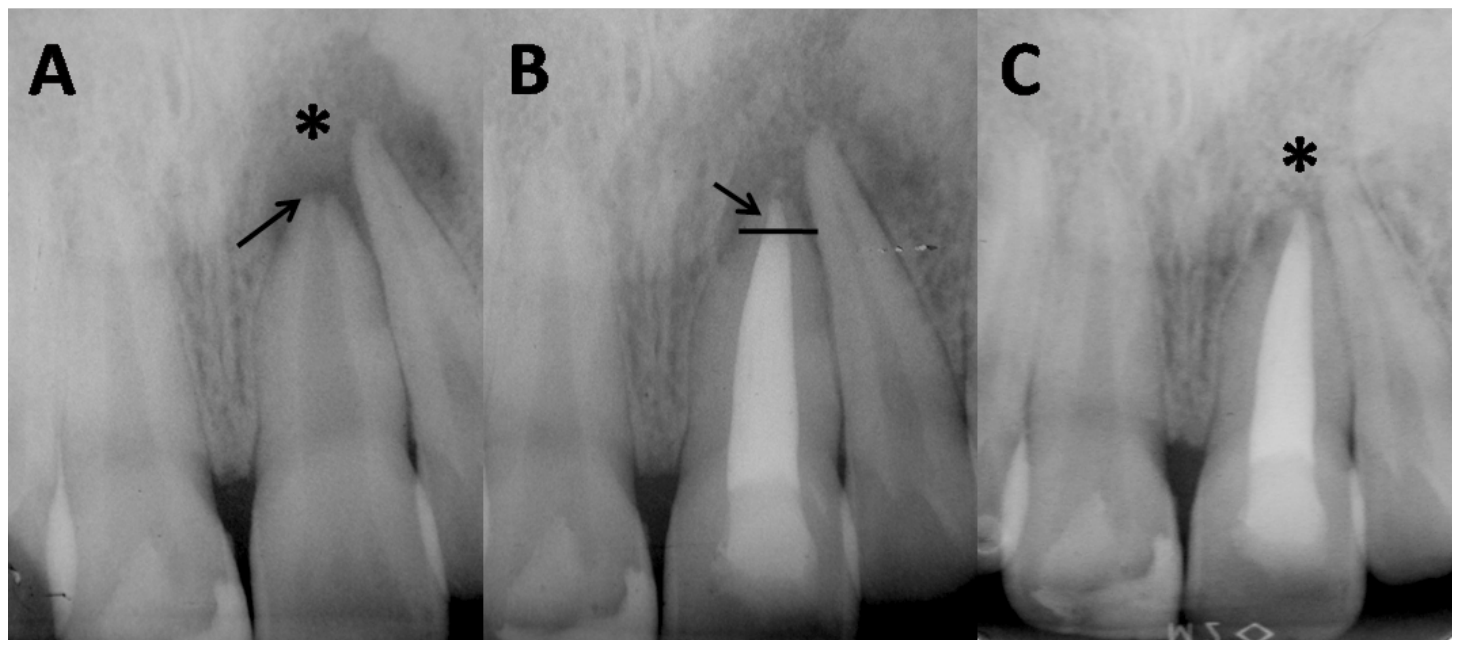

Fig. 1. Case 1. (A) tooth 21 presenting a wide canal, open apex (arrow) and extensive radiolucent lesion $\left({ }^{*}\right)$; (B) MTA apical plug (arrow) and decrease of periapical lesion after a period of 6 months; (C) complete remission of periapical radioluscence $\left({ }^{*}\right)$ after the period of 1 year.

\section{Case 2}

A 23-year-old female was referred to endodontic appointment after suffering trauma in the right mandibular teeth during her childhood. Clinically, the right mandibular first molar was not sensitive to cold tests. Occlusal composite restoration was present but no coronary fracture was detected. Also, mild coronary darkening and slight mobility could be observed. Radiographic exams (Fig. 2A) revealed the proximity of oclusal restoration to the pulp chamber, open apex and extensive radiolucent area associated with tooth 30. Pulp necrosis with chronic apical periodontitis was diagnosed for tooth 30 and root canal treatment was immediately indicated. As previously described for case 1, irrigation protocol was performed using $2 \%$ CHX alternated with saline solution, followed by a final irrigation using EDTA. However, root canals were enlarged by a crowndown technique using rotary files (Profile taper .04 and .06, DENTSPLY - Maillefer Ballaigues, Switzerland) up to a file 30.04 at the working length. Calcium hydroxide was placed into the root canals for one week. After this period, MTA plug was placed and root canals were obturated as described in Case 1. Clinically, the patient remained asymptomatic after the periods of 6 months and 1 year. Radiography after 6 months follow up (Fig. 2B) revealed that the periapical lesion reduced in size. Further reduction was observed after 1 year (Fig. 2C), indicating favorable response towards complete healing.

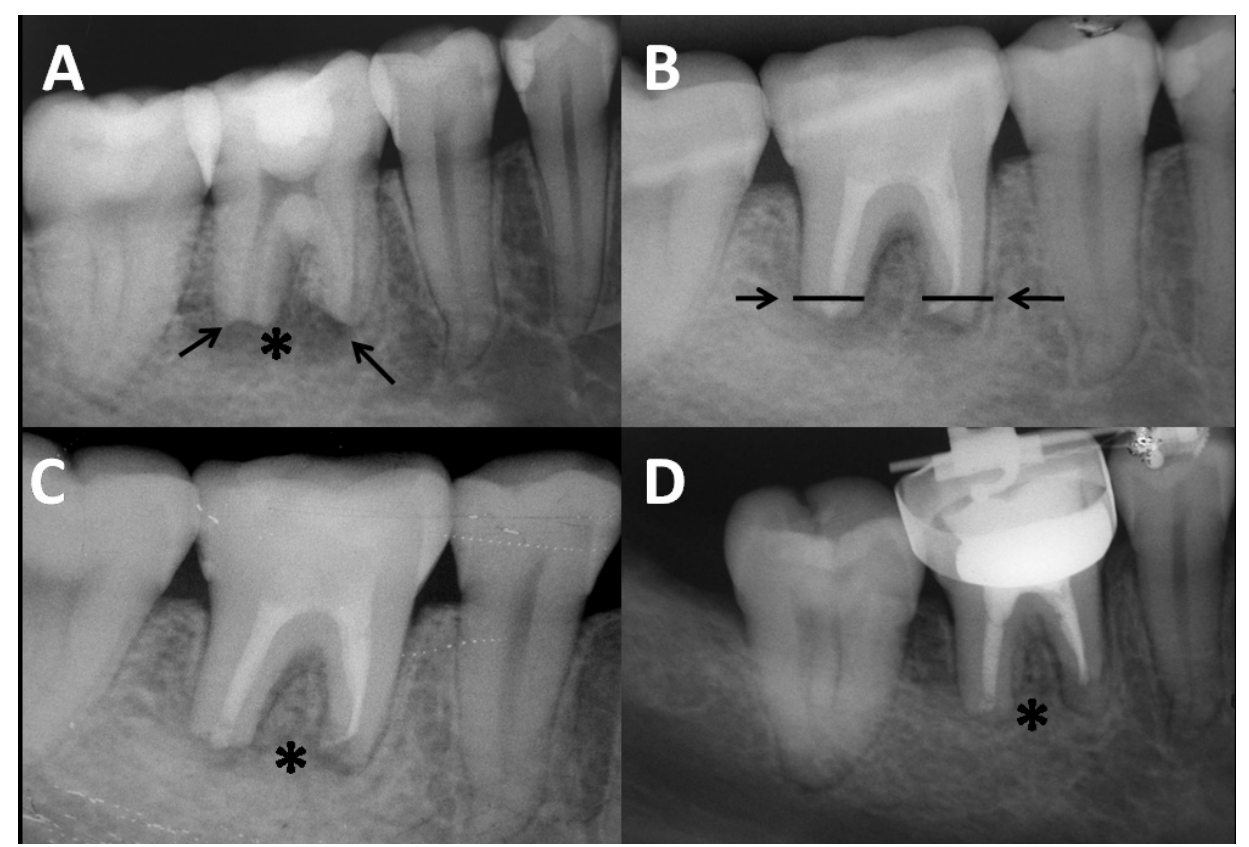

Fig. 2. Case 2. (A) tooth 46 with open apexes (arrows) and extensive radiolucent area $\left({ }^{*}\right)$; (B) MTA apical plugs (arrows) and $(C)$ decrease of periapical rarefaction after a period of 6 months; (D) further reduction of periapical radiolucence after the period of 1 year $\left({ }^{*}\right)$. 


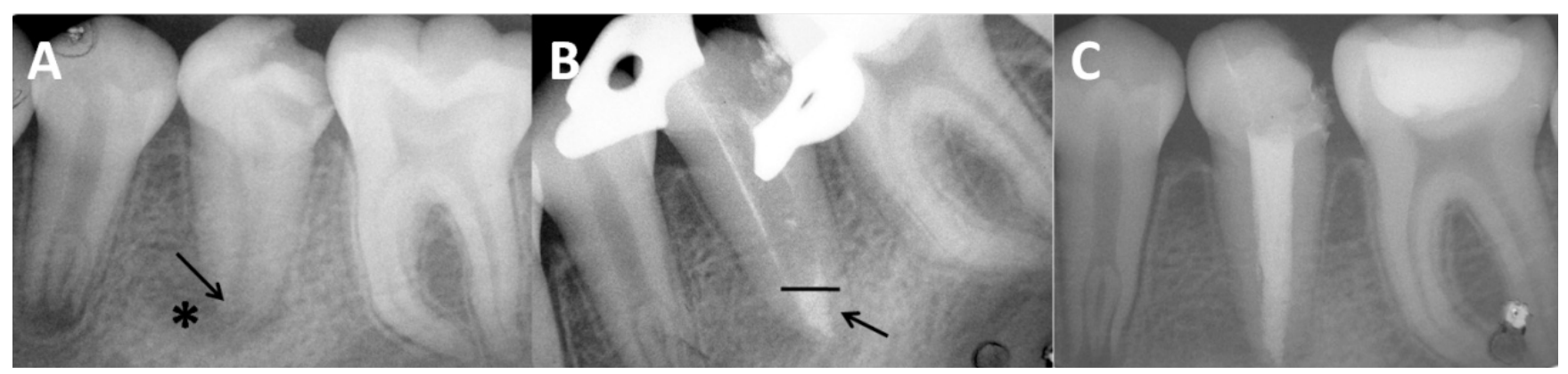

Fig. 3. Case 3. (A) tooth 35 presenting open apex (arrow) and extensive radiolucent area; (B) MTA apical plug (arrow); (C) reduction of periapical radiolucence after the period of 1 year.

\section{Case 3}

In the third case, a 14-year-old female with no significant medical history was referred to endodontic appointment due to an extensive decay located in her left mandibular second pre-molar. Clinical examinations revealed carious tissue on occlusal and distal sides and mild coronary darkening. A little drainage via fistula located in the buccal mucosa was also detected. Radiographically, (Fig. 3A) tooth \#20 with open apex and extensive radiolucent area associated to its apex was revealed. Pulp necrosis and chronic apical periodontitis was diagnosed and RCT was initiated.

The protocol of irrigation was the same previously described. In this case, however, the root canal was enlarged by using hand K-type files, by a crown-down technique, up to a file \# 60 at the working length. After one week of intracanal dressing with $\mathrm{CaOH} 2+2 \% \mathrm{CHX}$ paste the fistula had completely healed. No signs of secretion were detected and the patient was still asymptomatic. MTA plug was then established, as previously described (Fig. 3B). The root canal filling was performed according to cases 1 and 2 .

The one year follow-up radiographic examination showed a complete healing of the case (Fig. 3C).

\section{Discussion}

The cases reported herein demonstrated the applicability of MTA as a material used for apical plug in infected immature teeth. Although calcium hydroxide demonstrates satisfactory results on periapical repair and on obtaining an apical mineralized barrier, the use of MTA presents some advantages, such as the possibility of its placement in as little as one visit (10) or after 1 or 2 applications of root canal dressings (11), thus eliminating the waiting time required for calcium hydroxide apexification. This advantage is especially relevant because it has been proved that the placement of a permanent restoration after a short treatment time serves to increase fracture resistance of the immature teeth $(3,4)$. Also, calcium hydroxide long term treatment may increase the risk of root fracture (12).

In the present case report, it was chosen to use calcium hydroxide dressing associated to CHX before MTA placement. The use of this association has been recently suggested (19), being supported by the advantages of keeping important properties of calcium hydroxide i.e: its tissue solving effect (14) and its capacity of acting as a physical barrier preventing interappointment reinfection as well as increasing its antimicrobial effect (13-14).

CHX has been shown to be more effective than calcium hydroxide in eliminating $E$ faecalis infection inside dentinal tubules (13). For this reason it seems to be reasonable to associate its excellent antimicrobial capacity to calcium hydroxide.

The improvement of chemical capacity of disinfection seems to be especially relevant in cases of nonvital immature teeth, which present several challenges for promoting mechanical cleaning and shaping. Characteristics such as the presence of thin and fragile lateral walls and the large volume of necrotic debris contained in wide root canals make the achievement of sufficient disinfection difficult.

The treatment results obtained in the present study might be also related to the fact that MTA is capable of maintaining the biological properties presented by calcium hydroxide. MTA forms calcium oxide when in contact with water, which when placed in contact with fluids of tissues forms calcium hydroxide, and triggers the same repair process in tissues $(7,9)$. In addition, MTA physical characteristics of expansion during the attachment assist to the achievement of the apical sealing. A $4-5 \mathrm{~mm}$ apical plug is appropriate to resist displacement from the apex and to prevent infiltration of fluids in the canal (15).

In conclusion, MTA is a valid option for cases of immature teeth, with the advantage of a shorter chair-side treatment. 
1. Frank AL. Therapy for the divergent pulpless tooth by continued apical formation. J Am Dent Assoc 1966;72:78-93.

2. Holden DT, Schwartz SA, Kirkpatrick TC, Schindler WG. Clinical outcomes of artificial root-end barriers with mineral trioxide aggregate in teeth with immature apices. J Endod 2008;34:812-7.

3. Cvek M. Treatment of non-vital permanent incisors with calcium hydroxide: I- follow up of periapical repair and apical closure of immature roots. Odontol Revy 1972;23:27-44.

4. Andreassen JO, Munksgaard EC, Bakland LK. Comparison of fracture resistance in root canals of immature sheep teeth after filling with calcium hydroxide or MTA. Dent Traumatol 2006;22:154-6.

5. Sauders WP, Saunders EM. Coronal leakage as a cause of failure in root canal therapy: a review. Endod Dent Traumatol 1994;10:105-8.

6. Binnie WH, Rowe AHR. A histological study of periapical tissues of incompletely formed pulpless teeth filled with calcium hydroxide. J Dent Res 1973;52:1 1 10-6.

7. Torabinejad M, Watson TF, Pitt Ford TR. Sealing ability of mineral trioxide aggregate when used as a root end filling material. J Endod 1993;19:591-5.

8. Lee SJ, Monset M, Torabinejad M. Sealing ability of mineral trioxide aggregate for repair of lateral root perforations. J Endod. 1993;19:541-4.

9. Holland R, Souza V, Nery MJ, Bernabé PFE, Otoboni Fo JA, Dezan Jr E. Reaction of rat connective tissue to implanted dentin tubes filled with a white mineral trioxide aggregate. Braz Dent J. 2002;13:23-6.

10. Witherspoon DE, Ham K. One visit apexification: technique for inducing root-end barrier formationin apical closures. Pract Proced Aesthet Dent 2001;13:455-60.

11. Shabahang S, Torabinejad M. treatment of teeth with open apices using mineral trioxide aggregate. Pract Periodontics Aesthet Dent 2000;12:315-20.

12. Andreasen JO, Farik B, Munksgaard EC. Long-term calcium hydroxide as a root canal dressing may increase risc of root fracture. Dent Traumatol 2002;18:134-7.

13. Ercan E, Dalli M, Dülgergil CT. In vitro assessment of the effectiveness of chlorhexidine gel and calcium hydroxide paste with chlorhexidine against Enterococcus faecalis and Candida albicans. Oral Surg Oral Med Oral Pathol Oral Radiol Endod 2006;102:e27-31.

14. Haenni S, Schmidlin PR, Mueller B, Sener B, Zehnder M. Chemical and antimicrobial properties of calcium hydroxide mixed with irrigating solutions. Int Endod J 2003;36:100-5.

15. Orosco FA, Bramante CM, Garcia RB, Bernadineli N, Moraes IG. Sealing ability of gray MTA Angelus ${ }^{\top M}{ }^{2} C^{C P M}{ }^{\top M}$ and MBPC used as apical plugs. J Appl Oral Sci 2008; 16:50-4. 